$11-18-2009$

\title{
Suppression of ErbB-2 in androgen-independent human prostate cancer cells enhances cytotoxic effect by gemcitabine in an androgen-reduced environment.
}

\author{
Li Zhang \\ University of Nebraska Medical Center \\ Jeffrey S. Davis \\ University of Nebraska Medical Center \\ Stanislav Zelivianski \\ University of Nebraska Medical Center \\ Fen-Fen Lin \\ University of Nebraska Medical Center, flin@unmc.edu \\ Rachel Schutte \\ University of Nebraska Medical Center \\ Tell us how you used this information in this short survey. \\ Follow this and additional works at: https://digitalcommons.unmc.edu/com_bio_articles \\ See next page for additional authors \\ Part of the Medical Biochemistry Commons, and the Medical Molecular Biology Commons
}

\section{Recommended Citation}

Zhang, Li; Davis, Jeffrey S.; Zelivianski, Stanislav; Lin, Fen-Fen; Schutte, Rachel; Davis, Thomas L.; Hauke, Ralph; Batra, Surinder K.; and Lin, Ming-Fong, "Suppression of ErbB-2 in androgen-independent human prostate cancer cells enhances cytotoxic effect by gemcitabine in an androgen-reduced environment." (2009). Journal Articles: Biochemistry \& Molecular Biology. 37.

https://digitalcommons.unmc.edu/com_bio_articles/37

This Article is brought to you for free and open access by the Biochemistry \& Molecular Biology at DigitalCommons@UNMC. It has been accepted for inclusion in Journal Articles: Biochemistry \& Molecular Biology by an authorized administrator of DigitalCommons@UNMC. For more information, please contact digitalcommons@unmc.edu. 


\section{Authors}

Li Zhang, Jeffrey S. Davis, Stanislav Zelivianski, Fen-Fen Lin, Rachel Schutte, Thomas L. Davis, Ralph Hauke, Surinder K. Batra, and Ming-Fong Lin

This article is available at DigitalCommons@UNMC: https://digitalcommons.unmc.edu/com_bio_articles/37 


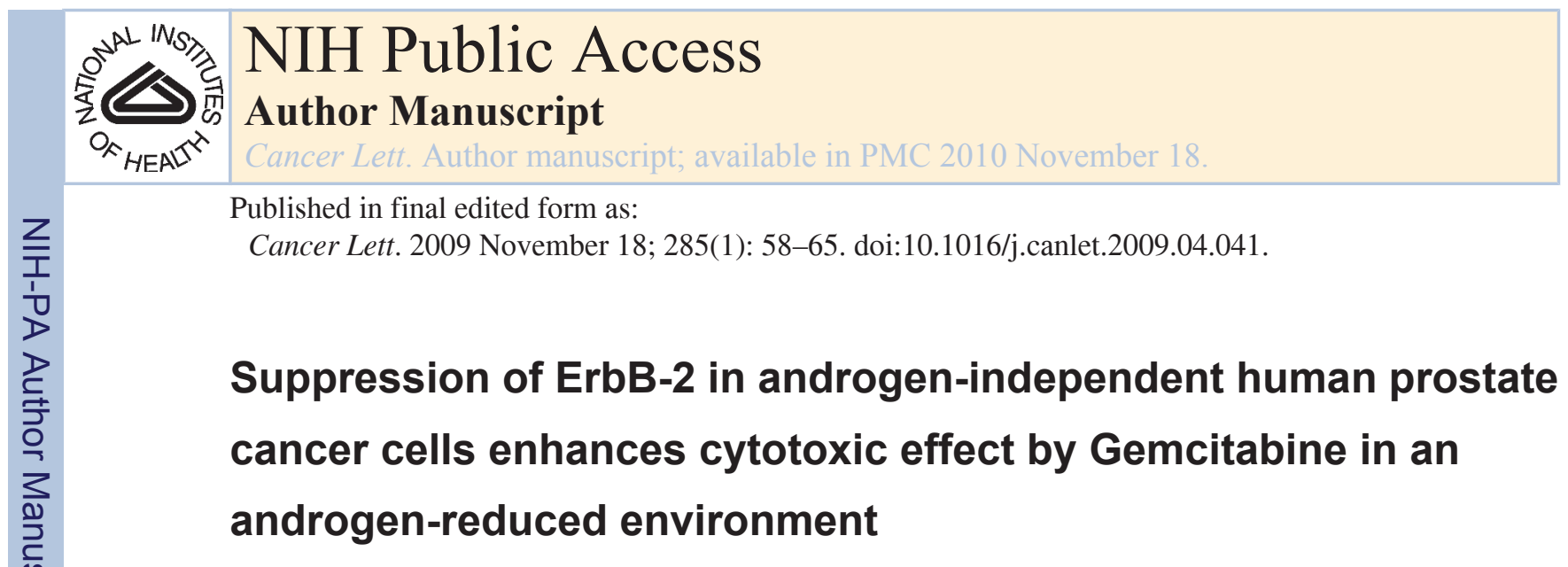

\author{
Li Zhang ${ }^{1}$, Jeffrey S. Davis ${ }^{1}$, Stanislav Zelivianski ${ }^{1}$, Fen-Fen Lin ${ }^{1}$, Rachel Schutte ${ }^{1}$, Thomas \\ L. Davis ${ }^{2}$, Ralph Hauke ${ }^{3}$, Surinder K. Batra ${ }^{1,4}$, and Ming-Fong Lin ${ }^{1,4}{ }^{*}$ \\ ${ }^{1}$ Department of Biochemistry and Molecular Biology, Omaha, NE 68198, USA \\ ${ }^{2}$ Nebraska Health System University Hospital, Omaha, NE 68198, USA \\ ${ }^{3}$ Department of Internal Medicine, College of Medicine and Nebraska Cancer Specialists, Omaha, \\ NE 68198, USA \\ ${ }^{4}$ Eppley Institute for Cancer Research, University of Nebraska Medical Center, Omaha, NE 68198, \\ USA
}

\begin{abstract}
We examined the efficacy of combination treatments utilizing cytotoxic drugs plus inhibitors to members of the ErbB - ERK signal pathway in human prostate cancer (PCa) LNCaP C-81 cells. Under an androgen-reduced condition, $50 \mathrm{nM}$ gemcitabine caused about $40 \%$ growth suppression on C-81 cells. Simultaneous treatment of gemcitabine plus $10 \mu$ M AG825 produced $60 \%$ suppression $(p<0.03)$; while, $85 \%$ growth inhibition $(p<0.02)$ was seen if AG825 was added to gemcitabinetreated cells after a $24 \mathrm{hr}$-interval. Our data thus showed that in androgen-reduced conditions, inhibition of ErbB-2 increases the cytotoxic efficacy of gemcitabine in PCa cells. This finding has significant implications in the choice of drugs for combination therapy as well as the order of administration for treating cancer patients.
\end{abstract}

\title{
Keywords
}

Hormone-refractory prostate cancer; Gemcitabine; ErbB-2 Inhibitor; Combination therapy

\section{Introduction}

Prostate cancer (PCa) is the second leading cause of male cancer mortality in the United States of America [1]. Several approaches, including surgery and radiation therapies, provide

(C) 2009 Elsevier Ireland Ltd. All rights reserved.

*All correspondence and reprint request should be addressed to: Ming-Fong Lin, Ph.D., Department of Biochemistry and Molecular Biology, University of Nebraska Medical Center, 985870 Nebraska Medical Center, Omaha, NE 68198-5870, USA, Tel. (402)559-6658, Fax. (402)559-6650, mlin@unmc.edu.

Publisher's Disclaimer: This is a PDF file of an unedited manuscript that has been accepted for publication. As a service to our customers we are providing this early version of the manuscript. The manuscript will undergo copyediting, typesetting, and review of the resulting proof before it is published in its final citable form. Please note that during the production process errors may be discovered which could affect the content, and all legal disclaimers that apply to the journal pertain.

Conflict of interest statement

The authors declare that there are no financial and personal relationships with other people or organisations that could inappropriately influence (bias) our work. 
clinicians with effective options for treating patients with localized cancer; while androgen ablation therapy remains the main choice for treating metastatic disease [2]. However, patients with advanced PCa benefit only temporarily from androgen deprivation treatment, and the disease progresses to hormone-refractory cancer [2]. Progress in treating this stage of PCa has been very modest with only one chemotherapeutic agent - docetaxel - having demonstrated any meaningful benefit. It is imperative to explore new therapeutic regimens with less toxicity and higher efficacy.

Members of the ErbB family, including epidermal growth factor receptor (EGFR) and its ligands and ErbB-2/HER-2/Neu, are frequently elevated and/or mutation-activated in a variety of malignant diseases $[3,4]$. The activation of the mitogen-activated protein kinases (MAPKs) can also contribute to tumorigenesis. In PCa, ErbB to MAPK signal pathway is activated, correlating with hormone-refractory cancer progression [5-7]. The EGFR expression level is suggested to be associated with Gleason scores as well as the androgen-independent stage, and therefore the inhibition of EGFR signaling may suppress tumor angiogenesis [8]. ErbB-2 signaling also plays a critical role in PCa progression and correlates with hormone-refractory proliferation $[9,10]$. These observations lead to the hypothesis that targeting the ErbB members to MAPK signaling pathway could have therapeutic potential on those cancer cells. Thus, developing inhibitors toward those molecules has been actively pursued for improving the efficacy of cancer therapy.

The members of the Bcl-2 family represent critical check points within apoptotic pathways. Bcl-2 promotes cell survival by suppressing cellular apoptosis [11]. In PCa, up-regulation of $\mathrm{Bcl}-2$ correlates with its progression to the advanced hormone-refractory stage and increases radiation resistance [11]. Conversely, pro-apoptotic Bax protein effectively antagonizes Bcl-2 action, thereby promoting apoptosis [12]. It appears that the ratio of anti-apoptotic proteins, e.g., Bcl-2 and Bcl- $\mathrm{X}_{\mathrm{L}}$, to pro-apoptotic proteins, e.g., Bax and Bad, determines at least in part how cells will respond to apoptotic or survival signals [12]. To implement this approach in practice is to shift the ratio to favor apoptosis by decreasing anti-apoptotic and/or increasing pro-apoptotic gene expression [13].

Combining different classes of drugs has proven effective in treating various cancers since the drug resistance of cancers is likely due to the heterogeneity of cancer cell populations.

Nevertheless, drug combinations tend to be more toxic to normal cells and patients are more susceptible to adverse side effects. A new strategy is thus critically needed. Inhibitors to protein tyrosine kinases (PTKs), including ErbB family members, have been shown to enhance the therapeutic efficacy of some conventional cytotoxic agents [7,14]. Combinations of MAP kinase/ERK kinase (MEK) inhibitors with docetaxel can increase cellular apoptosis in androgen-independent PCa cells under androgen-reduced conditions [7]. The same efficacy on cell growth suppression could be achieved by the combination treatment with a lower dose of cytotoxic agents plus inhibitors to signal transduction pathways, compared to combination therapies with conventional drugs.

Cancer treatment with DNA-damaging agents is commonly used in clinic. Gemcitabine (2', 2'-difluro-2'-deoxycytidine), an analog of deoxycytidine that inhibits DNA biosynthesis, exhibits effective anticancer activity toward several cancers [15]. It is also considered to be one of the most promising agents used in combination treatments $[14,16]$. Several clinical studies have analyzed the efficacy of combined treatments of gemcitabine plus other agents such as taxanes, vinorelbine, vindesine, cisplatin, 5-fluorouracil as well as anthracyclines across various regimens and conditions of pretreatment [17-19]. Most of those two-drug combination treatments have consistently demonstrated higher efficacy than either single agent. Importantly, recent studies reveal a potential synergistic effect by combination treatments with gemcitabine plus PTK inhibitors [20]. However, the efficacy of gemcitabine 
as a single agent or in combination utility for treating advanced PCa has yet to be fully investigated [21].

In this study, we investigated whether combination treatments could enhance the efficacy of gemcitabine for treating hormone-refractory $\mathrm{PCa}$, utilizing androgen-independent human $\mathrm{PCa}$ LNCaP C-81 cells as the model system. These LNCaP C-81 cells exhibit many biochemical features observed in clinical hormone-refractory $\mathrm{PCa}$ [22-24]. These cells thus serve as a useful cell model in designing novel therapeutic approaches toward androgen receptor (AR) -positive, androgen-independent $\mathrm{PCa}$, the major population of advanced PCa cells. We investigated if combination therapy of gemcitabine plus inhibitors to the ErbB signal pathway can reduce the effective dose of gemcitabine, alleviating its impact on normal cells and concurrently increasing its effect on growth suppression. To mimic clinical applications of chemotherapeutic agents during androgen ablation therapy of $\mathrm{PCa}$, we examined the combination efficacy on suppressing LNCaP C-81 cells in an androgen-reduced condition.

\section{Materials and methods}

\subsection{Materials}

Fetal bovine serum (FBS), cell culture medium RPMI 1640 and gentamicin were purchased from Invitrogen Life Technologies (Carlsbad, CA). Specific antibodies (Abs) to Bcl-2 and Bax and horseradish peroxidase-conjugated anti-mouse and anti-rabbit IgG Abs were from Santa Cruz Biotechnology (Santa Cruz, CA). Charcoal/Dextran-treated, certified FBS was from HyClone (Logan, UT). Docetaxel and gemcitabine were obtained from the Nebraska Health System University Hospital. PD98059, AG825 and AG1478 were from Calbiochem (San Diego, CA). All other reagents were obtained as described in previous publications [7,9].

\subsection{Cell culture}

Human PCa cell line LNCaP was purchased from the American Type Culture Collection and routinely maintained in the regular culture medium, i.e., phenol red (PR)-containing RPMI 1640 medium supplemented with $5 \%(\mathrm{v} / \mathrm{v}) \mathrm{FBS}, 2 \mathrm{mM}$ glutamine and $50 \mu \mathrm{g} / \mathrm{ml}$ gentamicin $[22,23]$. LNCaP parental cells are androgen-sensitive and express prostate-specific antigen (PSA). Upon passage, LNCaP cells gradually lost androgen sensitivity. For experiments, LNCaP C-81 cells that had passage numbers between 80 and 120 and exhibited androgenindependent growth were used as the model system [22,23]. Despite the expression of functional AR in LNCaP C-81 cells, the growth of C-81 cells is androgen-independent. Furthermore, C-81 cells exhibit many biochemical characteristics as seen in advanced hormone-refractory $\mathrm{PCa}$, for example, in the presence of castrated levels of androgens, those cells secrete PSA, exhibit rapid growth rates and high tumorigenecity in xenograft animals [22-24]. Importantly, these cells exhibit intracrine regulation by biosynthesizing testosterone from cholesterol as observed in some advanced $\mathrm{PCa}$ [25]. For determining cell growth, the total cell number was counted using a Coulter Counter Z1 model [9].

\subsection{Treatment with chemotherapeutic agents}

For experiments, cells were seeded in the regular medium for 2 days and then fed with a steroidreduced (SR) medium, i.e., phenol-red (PR)-free RPMI 1640 medium containing 5\% (v/v) heat-inactivated, charcoal/dextran-stripped fetal bovine serum (CS-FBS), $2 \mathrm{mM}$ glutamine and $50 \mu \mathrm{g} / \mathrm{ml}$ gentamicin. After 2 days, cells were fed with fresh SR medium and treated with PD98059, AG825, AG1478, gemcitabine, or docetaxel, either alone or in combination, as specified in each experiment, for 3 days [7]. To quantify the cell growth, attached cells were trypsinized and cell number was counted with a Coulter Counter. All experiments were done in triplicates and repeated at least twice. 


\subsection{Western blotting}

Briefly, cells were scraped, pelleted and rinsed with ice-cold HEPES-buffered saline, $\mathrm{pH}$ 7.0, and then lysed in an ice-cold cell lysis buffer containing a battery of protease and phosphatase inhibitors $[22,26]$. For immunoblotting, the nitrocellulose membrane filter was blocked and subsequently incubated with appropriate primary Ab. After rinsing, the filter was incubated with secondary Ab. The protein bands were visualized by an ECL detection system. For reblotting, filters were agitated with the stripping buffer for $30 \mathrm{~min}$ at $50^{\circ} \mathrm{C}[9,23]$.

\subsection{TUNEL assay}

A TUNEL assay Kit (Roche, Indianapolis, IN) was used to measure apoptosis [7]. Briefly, cells were plated on coverslips in regular culture medium for $48 \mathrm{hr}$ and then in SR medium for an additional $48 \mathrm{hr}$. Cells were fed with fresh SR medium with or without reagents for $72 \mathrm{hr}$. The apoptotic cells were detected by the commercial kit, following the accompanying protocol. Apoptotic cells were observed under a light microscope and were counted in 5 randomly selected fields.

\subsection{Data analysis}

All western blot experiments were conducted at least twice and the most representative results were presented. The intensities of hybridization bands were semi-quantified by densitometric analyses of films with different exposure time periods, utilizing the BioRad Gel-Doc Gel Imager [7]. The statistical procedures for $p$-value analysis were performed by the student t-test with two populations to determine significance of comparisons. $p<0.05$ was considered as significant difference.

\section{Results}

We analyzed the growth suppression by combination treatments, utilizing cytotoxic agents plus inhibitors to PTKs in clinic-relevant, androgen-independent human PCa LNCaP C-81 cells. The utilization of C-81 cells is because these cells exhibit many biochemical properties as seen in hormone-refractory PCa, e.g., in the absence of androgen, these cells secret PSA and exhibit high tumorigenecity [22-24]. To mimic the clinical scenario in which androgen ablation is the first line of treatment for patients with metastatic $\mathrm{PCa}$, all experiments were conducted in a steroid-reduced condition, in which phenol red-free medium was used because phenol red exhibits stimulatory activity on androgen-sensitive LNCaP cells [27] Initial results showed that both docetaxel and gemcitabine each inhibited the growth of $\mathrm{LNCaP} \mathrm{C}-81$ cells effectively, following a dose-response manner (Fig. 1A). Clinic-relevant doses of gemcitabine at $50 \mathrm{nM}$ and of docetaxel at $2.4 \mathrm{nM}$ alone inhibited the growth of C-81 cells by approximately $40 \%$ and $60 \%$, respectively (Fig. 1A, upper panel). Furthermore, TUNEL assay analyses revealed that growth inhibition on LNCaP C-81 cells by docetaxel and gemcitabine was at least in part due to their effects on the apoptotic pathway (Fig. 1A, lower panel). We found that the limited efficacy of growth suppression by these two cytotoxic agents was at least in part due to their concurrent effects on increasing anti-apoptotic Bcl-2 and Bcl- $\mathrm{X}_{\mathrm{L}}$ protein levels (Fig. 1B).

We initially analyzed the efficacy of combination treatment with gemcitabine plus docetaxel. Unexpectedly, the concurrent treatment of both cytotoxic agents did not enhance growth inhibition. Only approximately $30 \%$ growth inhibition was observed with this combination, lower than either agent alone (Fig. 2 , lane \#6 vs. \#2 \&3). Because several studies have shown that the ErbB-2 - MAPK/ERK pathway is activated in PCa cells, especially in advanced hormone-refractory cancer cells $[7,9,28]$, we examined growth suppression on C-81 cells by inhibitors to ErbB-2 and MEK, the up-stream of MAPK/ERK. Under androgen-reduced conditions, at $10 \mu \mathrm{M}$ concentration each, both ErbB-2 inhibitor AG825 and MEK inhibitor PD098059 as single agents inhibited the growth of those cells only about 15\% in a 3-day 
treatment (Fig. 2, lane \#4\&5). Unexpectedly, PD098059 abolished the cytotoxic effect of gemcitabine when both agents were administrated together (Fig. 2, lane \#7). Nevertheless, the combination of AG825 with gemcitabine exhibited an added effect with approximately $60 \%$ growth suppression ( $\mathrm{p}<0.03$, lane \#8 vs. \#2). Interestingly, a synergistic effect with over $80 \%$ growth suppression was obtained when AG825 was added to the culture 24h after their exposure to gemcitabine ( $p<0.02$, lane $\# 9$ vs. $\# 2 ; p<0.05$, \#9 vs. \#8). To rule out whether it is a cell line-specific phenomenon, we tested the combined AG825 and gemcitabine treatment on high passage MDA PCa2b cells, an AR-positive, androgen-independent PCa cells exhibiting similar biochemical properties to C-81 cells and hormone-refractory $\mathrm{PCa}$ [29]. Our data clearly showed that in the steroid-reduced condition, those cells also responded to the sequential, combined treatment as observed on LNCaP C-81 cells (data not shown). Thus, in androgenreduced conditions, AG825, but not PD98059, can enhance the cytotoxic effect by gemcitabine and a sequential combination treatment resulted in even greater growth suppression on ARpositive, androgen-independent $\mathrm{PCa}$ cells, representing the majority of hormone-refractory $\mathrm{PCa}$ in clinic.

To determine whether gemcitabine plus AG825 inhibited LNCaP C-81 cell growth by enhancing the apoptotic pathway, we analyzed the expression of pro-apoptotic protein Bax and anti-apoptotic proteins Bcl-2 and Bcl- $\mathrm{X}_{\mathrm{L}}$ in those treated cells. As shown in Fig. 3 (lane \#2), in $50 \mathrm{nM}$ gemcitabine alone-treated C-81 cells, comparing with control cells (lane \#1), Bax protein level was elevated by approximately 5 -fold, while the $\mathrm{Bcl}-\mathrm{X}_{\mathrm{L}}$ was also elevated by about $50 \%$ with only a minor increase of Bcl-2 protein level. Treatment with $2.4 \mathrm{nM}$ docetaxel alone (Fig. 3, lane \#3) resulted in an elevated Bax protein level by about 2-fold with slight elevation of Bcl-2 as well as Bcl-X $\mathrm{X}_{\mathrm{L}}$ protein level. AG825 and PD98059, at $10 \mu \mathrm{M}$ each, had only moderate effects on both pro- and anti-apoptotic proteins (lanes \#4\&5). When combined with gemcitabine, neither docetaxel (lane \#6) nor PD98059 (lane \#7) had a significant effect on decreasing anti-apoptotic protein levels nor enhancing pro-apoptotic protein levels in treated cells, comparing with gemcitabine alone-treated cells (Fig. 3, lane \#2). Interestingly, when AG825 was added to gemcitabine, Bcl-2 and Bcl- $\mathrm{X}_{\mathrm{L}}$ protein levels were decreased; lower than that of gemcitabine alone-treated cells, with no significant change in Bax protein in those cells (Fig. 3, lane \#8 vs. \#2). Additionally, when AG825 was introduced to the cell cultures 24-hr after gemcitabine treatment, the Bax protein level was further elevated; while both Bcl-2 and $\mathrm{Bcl}-\mathrm{X}_{\mathrm{L}}$ protein levels were further decreased. These results therefore provide with a mechanistic explanation that AG825-enhanced gemcitabine action on growth suppression in those cells.

We examined whether the inhibitor of EGFR could similarly enhance the susceptibility of C-81 cells to gemcitabine-induced apoptosis. C-81 cells were treated with the EGFR inhibitor AG1478 plus gemcitabine, compared with AG825 plus gemcitabine in a steroid-reduced condition. As shown in Fig. 4A, after a 72-hour treatment, $10 \mu \mathrm{M}$ AG1478 exhibited approximately a $15 \%$ growth suppression, similar to AG825 (lane \#3 vs. \#2). The combination of $10 \mu \mathrm{M}$ AG1478 plus $50 \mathrm{nM}$ gemcitabine produced only approximately $30 \%$ growth suppression (Fig. 4A, lane \#6). In the same set of experiments, $50 \mathrm{nM}$ gemcitabine plus $10 \mu \mathrm{M}$ AG825 achieved growth suppression by approximately $60 \%$ (Fig. 4A, lane \#5). Thus, in a steroid-reduced condition, inhibition of EGFR could not enhance the efficacy of gemcitabine on $\mathrm{C}-81$ cell growth suppression.

To elucidate further the molecular mechanisms of differential growth suppressions by gemcitabine plus AG825 vs. AG1478 on C-81 cells, we examined their effects on the expression levels of Bcl-2 and Bax proteins. In C-81 cells treated with either $50 \mathrm{nM}$ gemcitabine (lane \#4), $10 \mu \mathrm{M}$ AG1478 (lane \#3) or AG825 (lane\#2) alone, the level of anti-apoptotic Bcl-2 protein was elevated, higher than that in control cells (Fig. 4B). Furthermore, AG825 abolished gemcitabine-induced increases of $\mathrm{Bcl}-2$ protein level, resulting in expression levels even lower 
than in control cells (Fig. 4B, lane \#5, Fig. 3, lane \#8). Nevertheless, AG1478 enhanced gemcitabine-induced Bcl-2 protein level in those cells, compared with that in single agenttreated cells (Fig. 4B, lane \#6). Additionally, treatment of C-81 cells with gemcitabine or AG825, but not AG1478, resulted in an elevated pro-apoptotic Bax protein level (Fig. 4B, lane $\# 2$ \& 4). The increase of Bax protein level was further enhanced by the combination treatment of gemcitabine plus AG825, correlating with growth suppression (Fig. 4B, lane \#5). Although co-administration of AG1478 with gemcitabine could increase Bax protein level, in those cells, anti-apoptotic proteins Bcl-2 (Fig. 4B, lane \#6) and Bcl- $\mathrm{X}_{\mathrm{L}}$ (data not shown) were also greatly elevated. The data collectively provided a mechanistic explanation for the lack of enhanced efficacy of AG1478 in gemcitabine-induced apoptosis.

\section{Discussion}

The efficacy of chemotherapeutic regimens for treating advanced hormone-refractory PCa is limited [2,30-32]. The objective of this study is to investigate whether the combination of chemotherapeutic agents with PTK inhibitors can enhance the apoptotic pathway of androgenindependent human PCa cells in an androgen-reduced culture condition. We also elucidate the mechanism of improved efficacy as it relates to changes in apoptotic proteins.

We initially analyzed the effect of combination treatment of gemcitabine plus docetaxel. Each agent alone exhibits efficacy toward several cancers, and their combination treatments have shown promising results for treating advanced non-small cell lung cancer [33]. Our data revealed that simultaneous administration of gemcitabine and docetaxel does not have an added effect of growth suppression on androgen-independent PCa cells in an androgen-reduced condition (Fig 2). Unexpectedly, the efficacy of growth suppression was decreased. We found that adding docetaxel to gemcitabine decreases the amount of pro-apoptotic, Bax, compared with gemcitabine alone and failed to decrease the amounts of the anti-apoptotic proteins, Bcl$\mathrm{X}_{\mathrm{L}}$ and Bcl-2 (Fig 3).

We analyzed whether inhibitors to ErbB family members could add to the growth suppression by gemcitabine, due to the importance of the ErbB family members in PCa progression [8,9, $34]$ and hormone-refractory proliferation [9,10,35-37]. We also investigated whether the MEK inhibitor PD98059 could enhance gemcitabine efficacy because MAPK pathways are associated with prostate cell mitogenesis and androgen-ablation survival [28], and also because PD98059 can enhance docetaxel-induced apoptosis in androgen-independent PCa cells under steroid-reduced conditions [7]. Interestingly, only AG825, but not PD98059 or AG1478, could enhance the growth suppression induced by gemcitabine in AR-positive, androgenindependent $\mathrm{PCa}$ cells under a steroid-reduced condition. Our data thus support the notion that ErbB-2, but not EGFR, plays a critical role in the androgen-independent proliferation of those cells $[9,22,35,36]$. This observation that inhibition of EGFR activity in LNCaP C-81 cells does not enhance growth inhibition by gemcitabine is in parallel with the observations that inhibition of proliferation and induction of apoptosis is independent of EGFR activity in some other cancer cells $[38,39]$. Additionally, this combined treatment in steroid-reduced conditions should not have a profound effect on non-malignant prostate epithelia because they are androgen-sensitive cells and will not proliferate under this environment even in the absence of treatment.

Overexpression of Bcl-2 correlates with progression of a subgroup of $\mathrm{PCa}$ to the advanced hormone-refractory stage $[40,41]$. Conversely, Bax effectively counteracts Bcl-2 function, promoting cellular apoptosis. Therefore, alteration of their ratios for example by inhibition of Bcl-2 and activation of Bax would lead to an apoptotic signal. We also analyzed the expression level of Bcl- $\mathrm{X}_{\mathrm{L}}$ in those cells. Unexpectedly, blocking EGFR signaling does not enhance gemcitabine-induced apoptosis of LNCaP C-81 cells despite the fact that Bax level is up- 
regulated in those cells. The lack of enhancement of this combination treatment is at least in part due to a concomitant elevation of both Bcl-2 and Bcl- $\mathrm{X}_{\mathrm{L}}$ protein levels (Fig. 4B, lane \#6), which compromises the Bax activity induced by gemcitabine. Conversely, AG825 can enhance gemcitabine-induced growth suppression on androgen-independent LNCaP C-81 cells in a steroid-reduced condition, which is at least in part due to the inhibition of $\mathrm{Bcl}-2$ and $\mathrm{Bcl}-\mathrm{X}_{\mathrm{L}}$ and concurrently the elevation of Bax protein (Fig. 3). Our data reveal that combination treatments could achieve growth suppression at lower concentrations than single agents alone (Fig. 2, lane \#8 vs. Fig. 1). Our data further suggest that the sequential administration of gemcitabine and AG825 to patients could generate much more pronounced growth suppression than simultaneous administration of both agents (Fig. 2, lane \#9). For its potential clinical applications, further studies in sequential dosing regimens of traditional anti-tumor agents and signal transduction inhibitors are needed. Additionally, studies could also target the expression of various apoptotic proteins to shift the ratio by enhancing pro-apoptotic over anti-apoptotic proteins to favor cell death.

Collectively, our data clearly show that ErbB-2 inhibition could enhance the gemcitabineinduced apoptosis, despite that several clinical evaluations show little advantage of either agent in the monotherapy setting [32]. The data further highlight the important role of ErbB-2 protein involvement in $\mathrm{PCa}$ progression, leading to hormone-refractory tumors. The results may then serve as a platform for the future development of effective therapeutic approaches to advanced $\mathrm{PCa}$, particularly in the post-docetaxel patient for whom no standard-of-care exists. Further studies should address whether gemcitabine plus ErbB-2 inhibitor together with hormonal ablation therapy can delay the development of the androgen-independent phenotype and improve patient survival.

\section{Acknowledgments}

This study is supported in part by NIH grant (2R01 CA88184) and DOD (PC074289 \& PC050769). We thank Drs. Mark Kellerman and Matthew Spellman for participating in the early phase of studies and Dr. Suresh Veeramani for his valuable discussion and comments.

\section{References}

1. Jemal A, Murray T, Samuel A, Ghafoor A, Ward E, Thun MJ. Cancer Statistics, 2003, CA. Cancer J. Clin 2003;53:5-26.

2. Isaacs JT. The biology of hormone refractory prostate cancer. Why does it develop? Urol. Clin. North. Am 1999;26:263-273. [PubMed: 10361549]

3. Raymond E, Faivre S, Armand JP. Epidermal growth factor receptor tyrosine kinase as a target for anticancer therapy. Drugs 2000;60:15-23. [PubMed: 11129168]discussion 41-42

4. Di Marco E, Pierce JH, Fleming TP, Kraus MH, Molloy CJ, Aaronson SA, Di Fiore PP. Autocrine interaction between TGF alpha and the EGF-receptor: quantitative requirements for induction of the malignant phenotype. Oncogene 1989;4:831-838. [PubMed: 2755700]

5. Culig Z. Androgen receptor cross-talk with cell signalling pathways. Growth Factors 2004;22:179184. [PubMed: 15518241]

6. Chen L, He HY, Li HM, Zheng J, Heng WJ, You JF, Fang WG. ERK1/2 and p38 pathways are required for P2Y receptor-mediated prostate cancer invasion. Cancer Lett 2004;215:239-247. [PubMed: 15488643]

7. Zelivianski S, Spellman M, Kellerman M, Kakitelashvilli V, Zhou XW, Lugo E, Lee MS, Taylor R, Davis TL, Hauke R, Lin MF. ERK inhibitor PD98059 enhances docetaxel-induced apoptosis of androgen-independent human prostate cancer cells. Int. J. Cancer 2003;107:478-485. [PubMed: 14506750]

8. Di Lorenzo G, Tortora G, D'Armiento FP, De Rosa G, Staibano S, Autorino R, D'Armiento M, De Laurentiis M, De Placido S, Catalano G, Bianco AR, Ciardiello F. Expression of epidermal growth 
factor receptor correlates with disease relapse and progression to androgen-independence in human prostate cancer. Clin. Cancer Res 2002;8:3438-3444. [PubMed: 12429632]

9. Meng TC, Lee MS, Lin MF. Interaction between protein tyrosine phosphatase and protein tyrosine kinase is involved in androgen-promoted growth of human prostate cancer cells. Oncogene 2000;19:2664-2677. [PubMed: 10851066]

10. Signoretti S, Montironi R, Manola J, Altimari A, Tam C, Bubley G, Balk S, Thomas G, Kaplan I, Hlatky L, Hahnfeldt P, Kantoff P, Loda M. Her-2-neu expression and progression toward androgen independence in human prostate cancer. J. Natl. Cancer Inst 2000;92:1918-1925. [PubMed: 11106683]

11. Reed JC. Bcl-2 and the regulation of programmed cell death. J. Cell Biol 1994;124:1-6. [PubMed: 8294493]

12. Adams JM, Cory S. The Bcl-2 protein family: arbiters of cell survival. Science 1998;281:1322-1326. [PubMed: 9735050]

13. Hastak K, Gupta S, Ahmad N, Agarwal MK, Agarwal ML, Mukhtar H. Role of p53 and NF-kappaB in epigallocatechin-3-gallate-induced apoptosis of LNCaP cells. Oncogene 2003;22:4851-4859. [PubMed: 12894226]

14. Zhang L, Lau YK, Xia W, Hortobagyi GN, Hung MC. Tyrosine kinase inhibitor emodin suppresses growth of HER-2/neu-overexpressing breast cancer cells in athymic mice and sensitizes these cells to the inhibitory effect of paclitaxel. Clin. Cancer Res 1999;5:343-353. [PubMed: 10037184]

15. Hui YF, Reitz J. Gemcitabine: a cytidine analogue active against solid tumors. Am. J. Health. Syst. Pharm 1997;54:162-170. [PubMed: 9117804]

16. el-Rayes BF, Shields AF, Vaitkevicius V, Philip PA. Developments in the systemic therapy of pancreatic cancer. Cancer. Invest 2003;21:73-86. [PubMed: 12643012]

17. Govindan R, Garfield DH. Treatment approaches in patients with advanced non-small cell lung cancer and poor performance status. Semin. Oncol 2004;31:27-31. [PubMed: 15599832]

18. Schmid P, Krocker J, Schulz CO, Michniewicz K, Dieing A, Eggemann H, Heilmann V, Blohmer JU, Sezer O, Elling D, Possinger K. Primary chemotherapy with gemcitabine, liposomal doxorubicin and docetaxel in patients with locally advanced breast cancer: results of a phase I trial. Anticancer Drugs 2005;16:21-29. [PubMed: 15613900]

19. Ishii H, Furuse J, Nagase M, Yoshino M. Impact of gemcitabine on the treatment of metastatic pancreatic cancer. J. Gastroenterol. Hepatol 2005;20:62-66. [PubMed: 15610448]

20. Nelson JM, Fry DW. Akt, MAPK (Erk1/2), and p38 act in concert to promote apoptosis in response to ErbB receptor family inhibition. J. Biol. Chem 2001;276:14842-14847. [PubMed: 11278435]

21. Morant R, Bernhard J, Maibach R, Borner M, Fey MF, Thürlimann B, Jacky E, Trinkler F, Bauer J, Zulian G, Hanselmann S, Hürny C, Hering F. Response and palliation in a phase II trial of gemcitabine in hormone-refractory metastatic prostatic carcinoma. Swiss Group for Clinical Cancer Research (SAKK). Ann. Oncol 2000;11:183-188. [PubMed: 10761753]

22. Lin MF, Meng TC, Rao PS, Chang C, Schonthal AH, Lin FF. Expression of human prostatic acid phosphatase correlates with androgen-stimulated cell proliferation in prostate cancer cell lines. J. Biol. Chem 1998;273:5939-5947. [PubMed: 9488733]

23. Igawa T, Lin FF, Lee MS, Karan D, Batra SK, Lin MF. Establishment and characterization of androgen-independent human prostate cancer LNCaP cell model. Prostate 2002;50:222-235. [PubMed: 11870800]

24. Denmeade SR, Sokoll LJ, Dalrymple S, Rosen DM, Gady AM, Bruzek D, Ricklis RM, Isaacs JT. Dissociation between androgen responsiveness for malignant growth vs. expression of prostate specific differentiation markers PSA, hk2, and PSMA in human prostate cancer model. The Prostate 2003;54:249-257. [PubMed: 12539223]

25. Dillard PR, Lin MF, Khan SA. Androgen-independent prostate cancer cells acquire the complete steroidogenic potential of synthesizing testosterone from cholesterol. Mol. Cellu. Endo 2008;295:115-120.

26. Meng TC, Lin MF. Tyrosine phosphorylation of c-ErbB-2 is regulated by the cellular form of prostatic acid phosphatase in human prostate cancer cells. J. Biol. Chem 1998;273:22096-22104. [PubMed: 9705354] 
27. Lin MF, Lee MS, Garcia-Arenas R, Lin FF. Differential responsiveness of prostatic acid phosphatase and prostate-specific antigen mRNA to androgen in prostate cancer cells. Cell Biol. Int 2000;24:681689. [PubMed: 11023645]

28. Gioeli D, Mandell JW, Petroni GR, Frierson HF Jr, Weber MJ. Activation of mitogen-activated protein kinase associated with prostate cancer progression. Cancer Res 1999;59:279-284. [PubMed: 9927031]

29. Chen SJ, Karan D, Johansson SL, Lin FF, Zeckser J, Singh AP, Batra SK, Lin MF. Prostate-derived factor as a paracrine and autocrine factor for the proliferation of androgen receptor-positive human prostate cancer cells. The Prostate 2007;67:557-571. [PubMed: 17221842]

30. Ziada A, Barqawi A, Glode LM, Varella-Garcia M, Crighton F, Majeski S, Rosenblum M, Kane M, Chen L, Crawford ED. The use of trastuzumab in the treatment of hormone refractory prostate cancer; phase II trial. Prostate 2004;60:332-337. [PubMed: 15264245]

31. Tang DG, Porter AT. Target to apoptosis: a hopeful weapon for prostate cancer. Prostate 1997;32:284293. [PubMed: 9288188]

32. van der Poel HG. Smart drugs in prostate cancer. Eur. Urol 2004;45:1-17. [PubMed: 14667509]

33. Giaccone G. Gemcitabine plus taxane combinations in non-small cell lung cancer. Semin. Oncol 1999;26:19-24. [PubMed: 10201517]

34. Sherwood ER, Van Dongen JL, Wood CG, Liao S, Kozlowski JM, Lee C. Epidermal growth factor receptor activation in androgen-independent but not androgen-stimulated growth of human prostatic carcinoma cells. Br. J. Cancer 1998;77:855-861. [PubMed: 9528825]

35. Lee MS, Igawa T, Yuan TC, Zhang XQ, Lin FF, Lin MF. ErbB-2 signaling is involved in regulating PSA secretion in androgen independent human prostate cancer LNCaP cells. Oncogene 2003;22:781-796. [PubMed: 12569372]

36. Freeman MR. HER2/HER3 heterodimers in prostate cancer: Whither HER1/EGFR? Cancer Cell 2004;6:427-428. [PubMed: 15542423]

37. Mellinghoff IK, Vivanco I, Kwon A, Tran C, Wongvipat J, Sawyers CL. HER2/neu kinase-dependent modulation of androgen receptor function through effects on DNA binding and stability. Cancer Cell 2004;6:517-527. [PubMed: 15542435]

38. Chen Z, Zhang X, Li M, Wang Z, Wieand HS, Grandis JR, Shin DM. Simultaneously targeting epidermal growth factor receptor tyrosine kinase and cyclooxygenase-2, an efficient approach to inhibition of squamous cell carcinoma of the head and neck. Clin. Cancer Res 2004;10:5930-5939. [PubMed: 15355926]

39. Campiglio M, Locatelli A, Olgiati C, Normanno N, Somenzi G, Vigano L, Fumagalli M, Menard S, Gianni L. Inhibition of proliferation and induction of apoptosis in breast cancer cells by the epidermal growth factor receptor (EGFR) tyrosine kinase inhibitor ZD1839 ('Iressa') is independent of EGFR expression level. J. Cell Physiol 2004;198:259-268. [PubMed: 14603528]

40. Kyprianou N, King ED, Bradbury D, Rhee JG. bcl-2 over-expression delays radiation-induced apoptosis without affecting the clonogenic survival of human prostate cancer cells. Int. J. Cancer 1997;70:341-348. [PubMed: 9033638]

41. McDonnell TJ, Troncoso P, Brisbay SM, Logothetis C, Chung LW, Hsieh JT, Tu SM, Campbell ML. Expression of the protooncogene bcl-2 in the prostate and its association with emergence of androgenindependent prostate cancer. Cancer Res 1992;52:6940-6944. [PubMed: 1458483] 

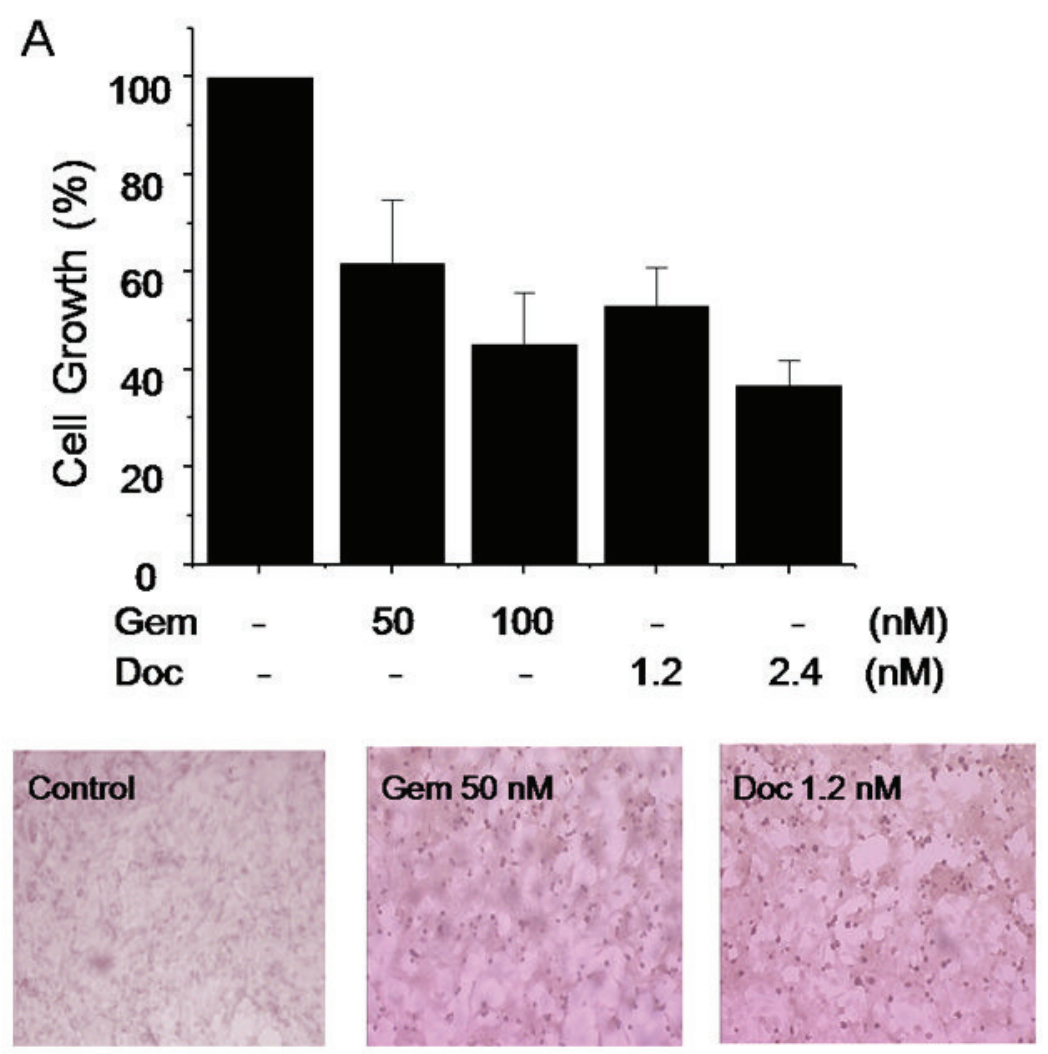

B

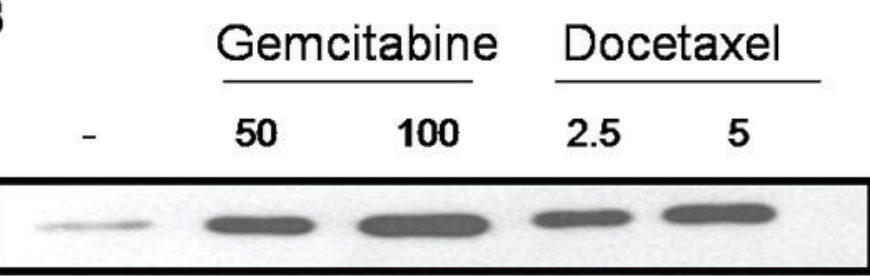

(nM)

$\mathrm{Bcl}-2$

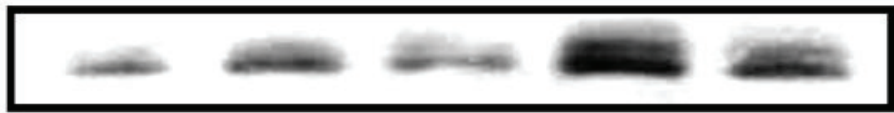

$\mathrm{Bcl}-\mathrm{X}_{\mathrm{L}}$

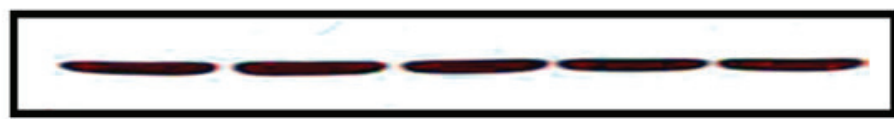

$\beta$-Actin

Fig. 1.

Chemosensitivity of LNCaP C-81 cells to gemcitabine or docetaxel in a steroid-reduced condition. (A) Upper panel: LNCaP C-81 cells were cultured in androgen-reduced conditions for $48 \mathrm{hrs}$ and then were treated with docetaxel or gemcitabine alone for 72 hours. Cells were harvested, and total cell number was counted. Bar represents SEs of triplicates in 2 sets of independent experiments. Lower panel: TUNEL Assay for control cells treated with vehicle alone (Control), cells treated with $50 \mathrm{nM}$ gemcitabine (Gem) or $1.2 \mathrm{nM}$ Docetaxel (Doc). (B) An equal amount of total cell lysate proteins was separated by SDS-PAGE and transferred to nitrocellulose membranes. The membranes were blotted with antibodies against of Bcl-2 or 
$\mathrm{Bcl}-\mathrm{X}_{\mathrm{L}}$. Hybridization with anti- $\beta$-actin $\mathrm{Ab}$ was used as a loading control for each lane. Similar results were obtained from at least 2 sets of independent experiments. 


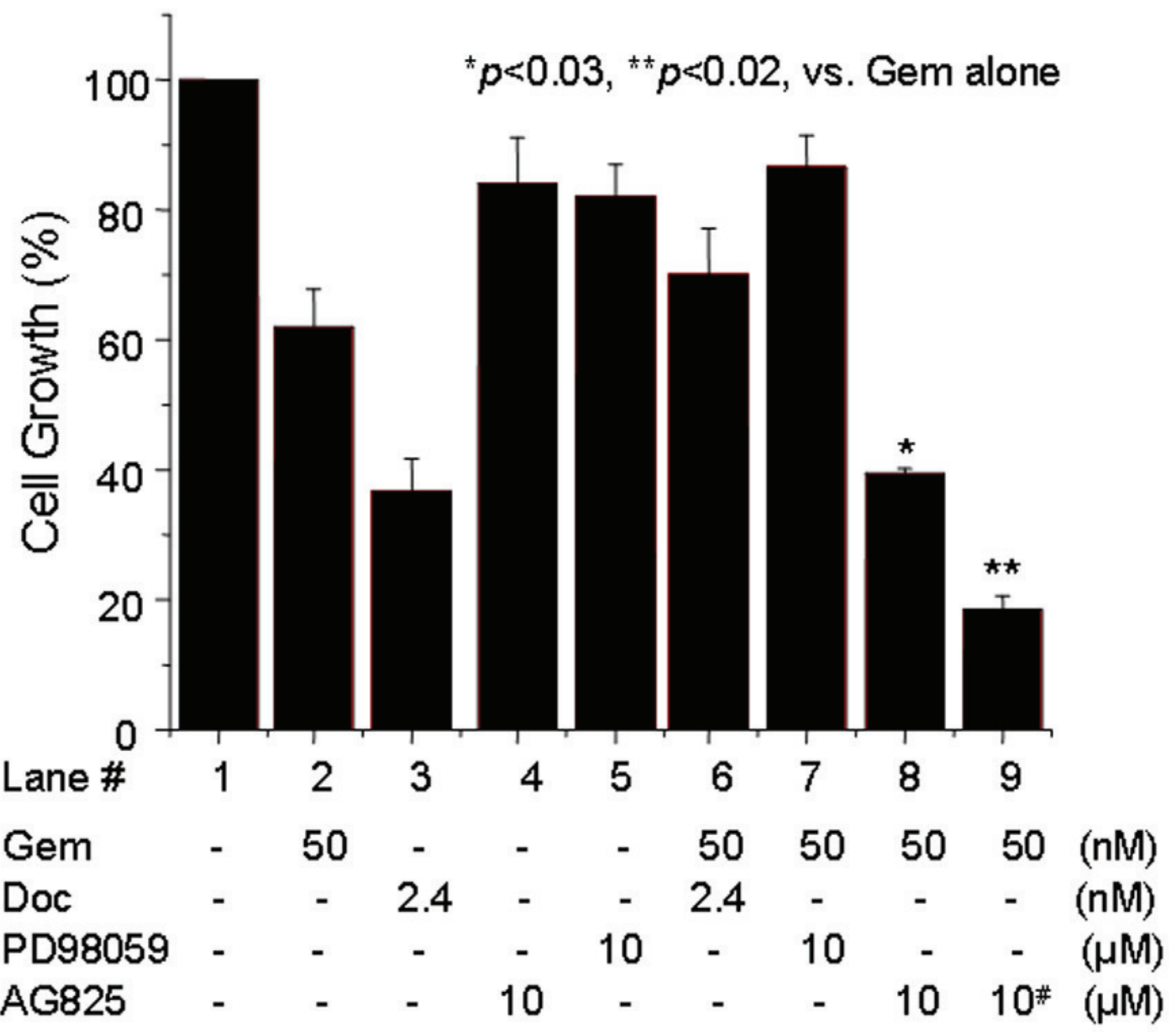

\section{\# Inhibitor AG825 given $24 \mathrm{~h}$ after treatment with Gemcitabine.}

Fig. 2.

Growth suppression of LNCaP C-81 cells by combination treatments of gemcitabine,

Docetaxel and ErbB-2 inhibitor in steroid-reduced conditions. C-81 cells in androgen-reduced conditions were treated with gemcitabine (Gem, $50 \mathrm{nM}$ ), docetaxel (Doc, $2.4 \mathrm{nM}), 10 \mu \mathrm{M} \mathrm{AG}$ $825,10 \mu \mathrm{M}$ PD 98059 or different combinations as indicated in the figure for 3 days. Control cells received solvent alone. Cell growth was measured by cell counting. The treatment in each lane is as follows: lane 1- solvent alone; lane 2-50 nM gemcitabine alone; lane 3- $2.4 \mathrm{nM}$ docetaxel alone; lane 4- $10 \mu \mathrm{M}$ AG825 alone; lane 5-10 $\mu \mathrm{M}$ PD98059 alone; lane 6-

Simultaneous treatment of $50 \mathrm{nM}$ gemcitabine plus $2.4 \mathrm{nM}$ docetaxel; lane 7- Simultaneous treatment of $50 \mathrm{nM}$ gemcitabine plus $10 \mu \mathrm{M}$ PD98059; lane 8-Simultaneous treatment of 50 nM gemcitabine plus $10 \mu \mathrm{M}$ AG825; lane 9-10 $\mu \mathrm{M}$ AG825 given 24h after treatment with gemcitabine. Bars represent SEs of triplicates in 3 sets of independent experiments. ${ }^{*} p<0.03$, 
growth inhibition by $50 \mu \mathrm{M}$ gemcitabine plus $10 \mu \mathrm{M}$ AG825 vs. $50 \mu \mathrm{M}$ gemcitabine alone; $* * \mathrm{p}<0.02$, growth inhibition by $50 \mu \mathrm{M}$ gemcitabine plus $10 \mu \mathrm{M}$ AG825 in which AG825 was added after 24 hours treatment with gemcitabine vs. $50 \mu \mathrm{M}$ gemcitabine alone. 

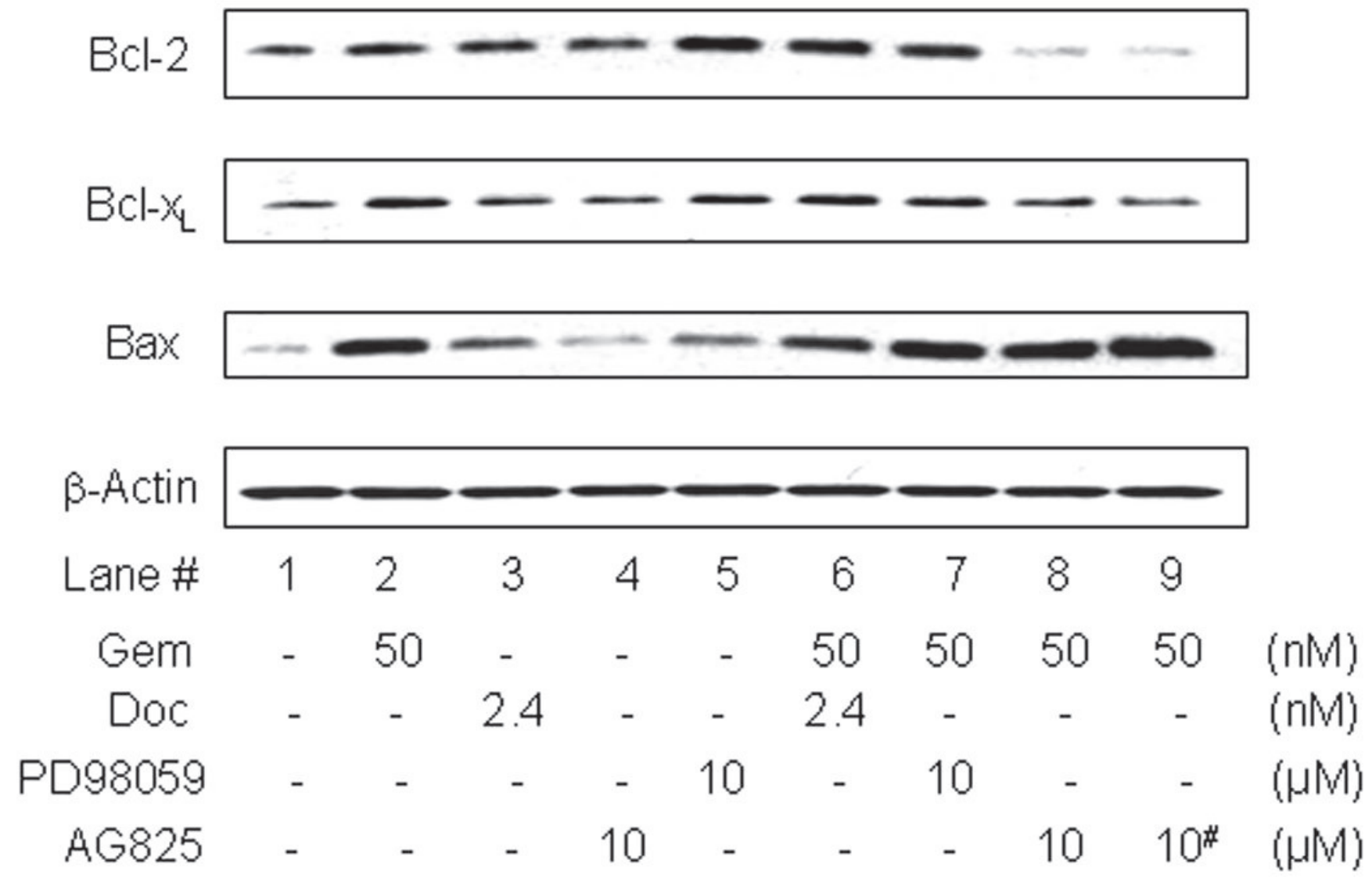

\section{\# Inhibitor AG825 given 24 h after treatment with Gemcitabine}

Fig. 3.

Molecular analyses on growth-suppressed LNCaP C-81 cells by combined treatments with gemcitabine, docetaxel and ErbB-2 inhibitor. C-81 cells in androgen-reduced conditions were treated with gemcitabine (Gem, $50 \mathrm{nM}$ ), docetaxel (Doc, $2.4 \mathrm{nM}$ ), $10 \mu \mathrm{M}$ AG 825, $10 \mu \mathrm{M}$ PD98059 or different combinations as indicated in the figure for 3 days. Control cells received solvent alone. The treatment in each lane is as follows: lane 1- solvent alone; lane $2-50 \mathrm{nM}$ gemcitabine alone; lane 3- 2.4 nM docetaxel alone; lane 4- $10 \mu \mathrm{M}$ AG825 alone; lane 5-10 $\mu \mathrm{M}$ PD98059 alone; lane 6- Simultaneous treatment of $50 \mathrm{nM}$ gemcitabine plus $2.4 \mathrm{nM}$ docetaxel; lane 7- Simultaneous treatment of $50 \mathrm{nM}$ gemcitabine plus $10 \mu \mathrm{M}$ PD98059; lane 8-Simultaneous treatment of $50 \mathrm{nM}$ gemcitabine plus $10 \mu \mathrm{M}$ AG825; lane 9-10 $\mu \mathrm{M}$ AG825 given 24h after treatment with gemcitabine. An aliquot of total cell lysates containing an equal amount of proteins was separated by SDS-PAGE and then transferred to nitrocellulose membranes. The membranes were blotted with antibodies against Bcl-2, Bcl- $\mathrm{X}_{\mathrm{L}}$ or Bax. Hybridization of the same membrane with anti- $\beta$-actin $\mathrm{Ab}$ was used as a loading control for each lane. Similar results were obtained from at least 3 sets of independent experiments. 
A

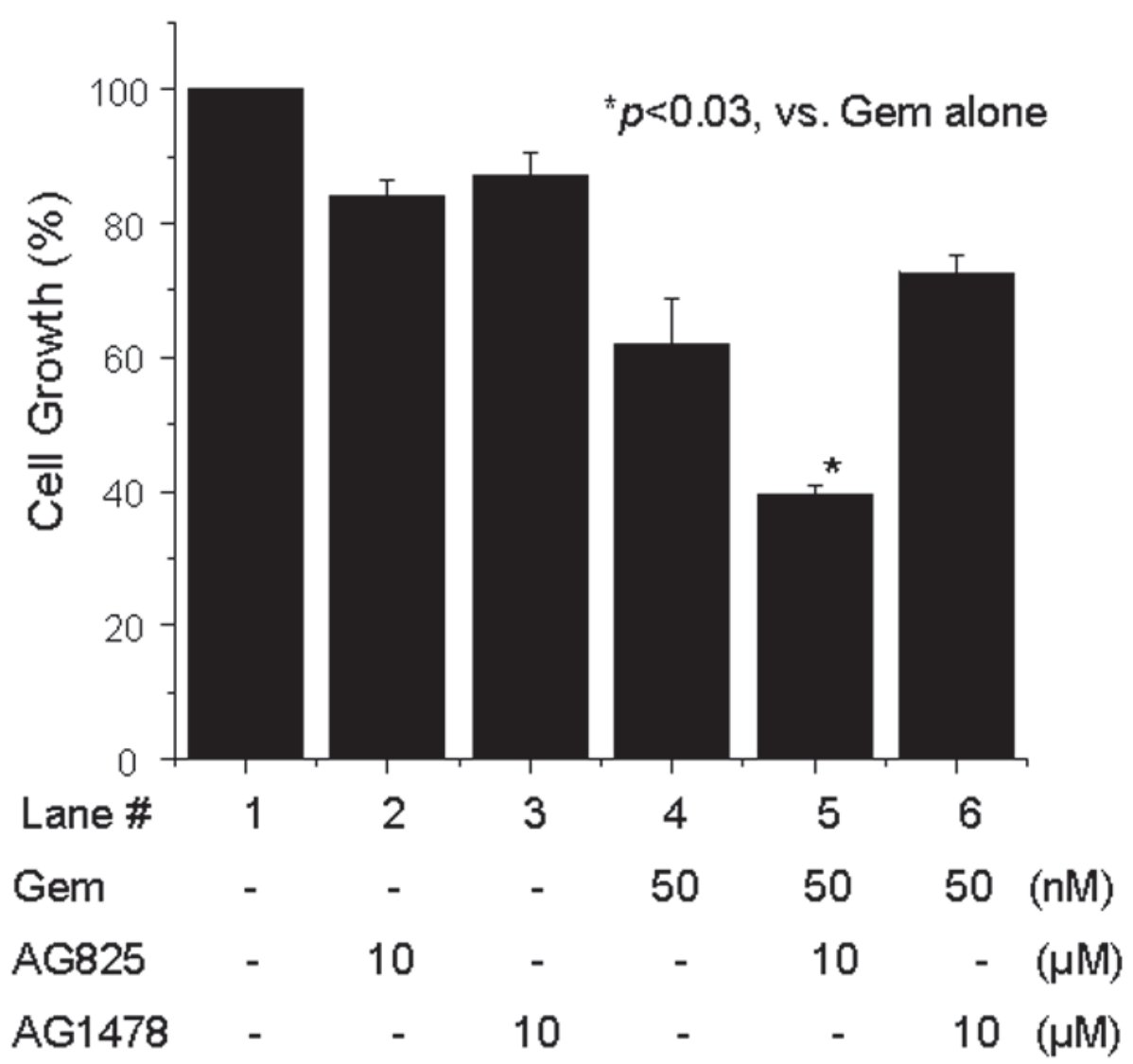

$\mathrm{B}$

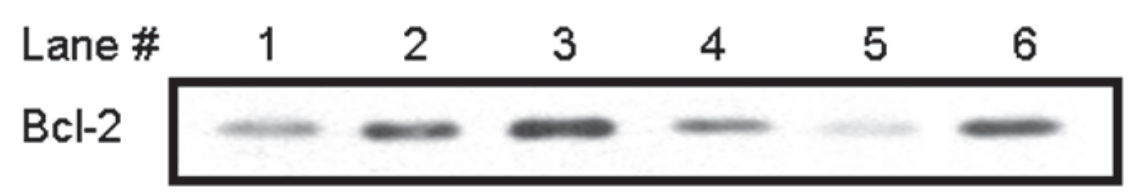

Bax
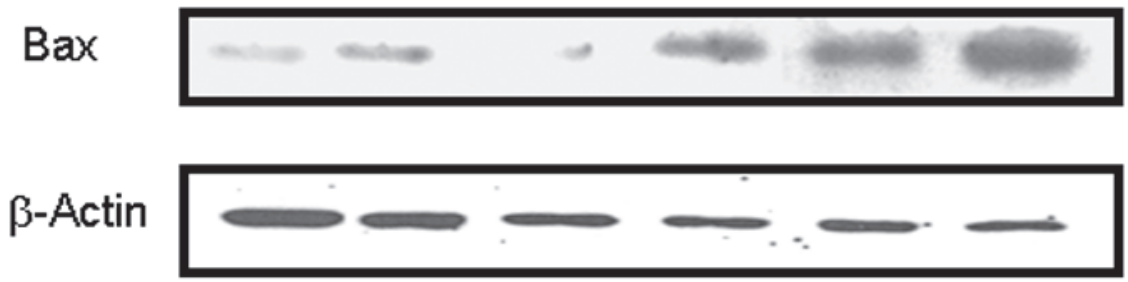

Fig. 4.

Growth suppression of LNCaP C-81 cells by combination treatment of gemcitabine and ErbB inhibitors. The C-81 cells in androgen-reduced conditions were treated with $50 \mathrm{nM}$ gemcitabine (Gem) in the presence or absence of $10 \mu \mathrm{M}$ AG 825 or $10 \mu \mathrm{M}$ AG1478 for 3 days. Control cells received solvent alone. (A) Cell growth was determined by cell counting. Bars represent SEs of triplicates in 2 sets of independent experiments. ${ }^{*} p<0.03$, growth inhibition by gemcitabine plus $10 \mu \mathrm{M}$ AG825 (lane \#5) vs. gemcitabine alone (lane \#4). (B) An equal amount of total cell lysate proteins was separated by SDS-PAGE and transferred to nitrocellulose membranes. The membranes were blotted with antibodies against of Bcl-2 or Bax. 
Hybridization of the same membrane with anti- $\beta$-actin $\mathrm{Ab}$ was used as a loading control for each lane. Similar results were obtained from at least 2 sets of independent experiments. 